\title{
SOME UNUSUAL PARASELLOIDEA (ISOPODA, ASELLOTA) FROM THE DEEP BENTHOS OF THE ATLANTIC
}

\author{
BY \\ GEORGE D. WILSON and ROBERT R. HESSLER \\ Scripps Institution of Oceanography, La Jolla, California 92037, U.S.A.
}

\section{INTRODUCTION}

It is nearly a truism that in the deep-sea benthos supraspecific taxa tend to be cosmopolitan. As a result, additional sampling only rarely yields radically new morphological types, even in poorly studied parts of the ocean. As an unusual exception to this rule, two adjacent stations in the equatorial Atlantic, made on "Atlantis II" cruise no. 31, were found to be populated by two species of paraselloid isopods which are quite aberrant in their general body and limb form. The unusual morphologies exhibited by these species clearly require the definition of new genera, Abyssaranea and Tbylakogaster, to contain them.

These genera have restricted distributions despite the fairly extensive sampling in the Atlantic that has taken place in the past decade. Thylakogaster has appeared in only three different areas, and only once on the extensively sampled Gay HeadBermuda transect (Sanders et al., 1965; Hessler \& Sanders, 1967). Abyssaraned at present is known only from the Equatorial Atlantic, and Munella was known prior to this paper, which records it from Bermuda, from the Bay of Biscay and the Mediterranean Sea (Bonnier, 1896; Lo Bianco, 1930). This patchy geographic distribution probably cannot be explained by some unusual geographic isolating factor since the stations listed in this paper yielded other Paraselloidea more common to the deep-sea fauna. One can only speculate on possible ecological factors that may be affecting the distributions of these genera. Thylakogaster tends to be badly fragmented during collection so that there may have been potential past records which were not reported due to the unrecognizable condition of the material. It is probable that more careful sampling in other areas will bring to light more populations and species of the genera described herein, though they might not prove to be cosmopolitan as are many deep-sea isopod genera.

These species do belong to a confusing cluster grouped within the families Munnidae and Dendrotionidae. Our inability to satisfactorily include the genera of this paper in any of these families, as presently defined, documents the great need for a general revision. However, such an effort is beyond the scope of the present study and will be attempted in a future paper.

Methods for collection and for preparing the taxonomic descriptions can be 
found in Hessler (1970). Unless otherwise noted, all measurements are based on single individuals. The specimens on which this article is based are presently located in the second author's working collection. The holotypes and some paratypes have been deposited in the United States National Museum (USNM). Other paratypes are deposited in the Zoological Museum of the University of Copenhagen (ZMUC).

The authors would like to thank Dr. Abraham Fleminger, Mr. William Riedel, and Mr. David Thistle for reading the manuscript and of fering helpful criticisms. We also thank Mr. Bryan Burnett for his capable rendering of the pencil drawings into ink. Drs. R. Ginet and J. Forest kindly attempted to locate the holotype of Munella danteci. This work, which was supported by National Science Foundation grants GA 810, GB 14488, GB 6027X, and GA 31344X, is a contribution of the Scripps Institution of Oceanography and the Woods Hole Oceanographic Institution (Contribution no. 2924).

\section{SYSTEMATICS}

\section{Thylakogaster new genus}

Type species. - Thylakogaster peterpauli n. sp. (figs. 1, 2).

Diagnosis. - Cephalon partially recessed into first pereonite. Body robust; depth at pereonite 3 greater than one third cephalon-pereon length. Pleon reflected anteriorly, lying above pereonites; very large, hollow, expanded dorsally and laterally into somewhat bilobed form; respiratory pleopods occupy only small portion of large branchial cavity (fig. 1e). External surfaces of pleopods 1 and 2 and lateral and posterior sides of pleon with many long, spinous outpocketings of cuticle; dorsum of pleon devoid of such spines; spines may also appear on coxae, lateral margins of pereonites 1 and 2 , and on dorso-lateral sides of cephalon.

Antennula of copulatory male slightly longer than body, with multiarticulate flagellum supplied with numerous aesthetascs, up to 8 per article. Antenna 3.1 times cephalon pereon length, with articles 5 and 6 accounting for most $(0.7)$ of length; flagellum approximately half length of article 6. Mandible without palp; molar process tapers distally into tuft of thin, curved spines. Palp of maxilliped long and narrow, all articles less than half width of basis; epipodite small, triangular, width less than basis, very short, height being less than half basis. First pereopod robust, subchelate, with major hinge between carpus and propodus; dactylus tightly articulated with propodus, with single claw. Second and third pereopods raptorial in appearance, with large setae; each limb approximately 2 times cephalon-pereon length, with greater than two thirds total length made up by carpus and propodus; dactylus short, finely setose, with single claw. Pereopods IV-VII longer than pereopods II and III, less robust, with smaller setae, and with long, slender claw and second vestigial claw on dactylus. First pleopod of copulatory male with sagittate posterior margin. Uropods without distinct rami, flattened, positioned on ventral margin of pleonal cavity in pockets close to posterior tip of pleon. 


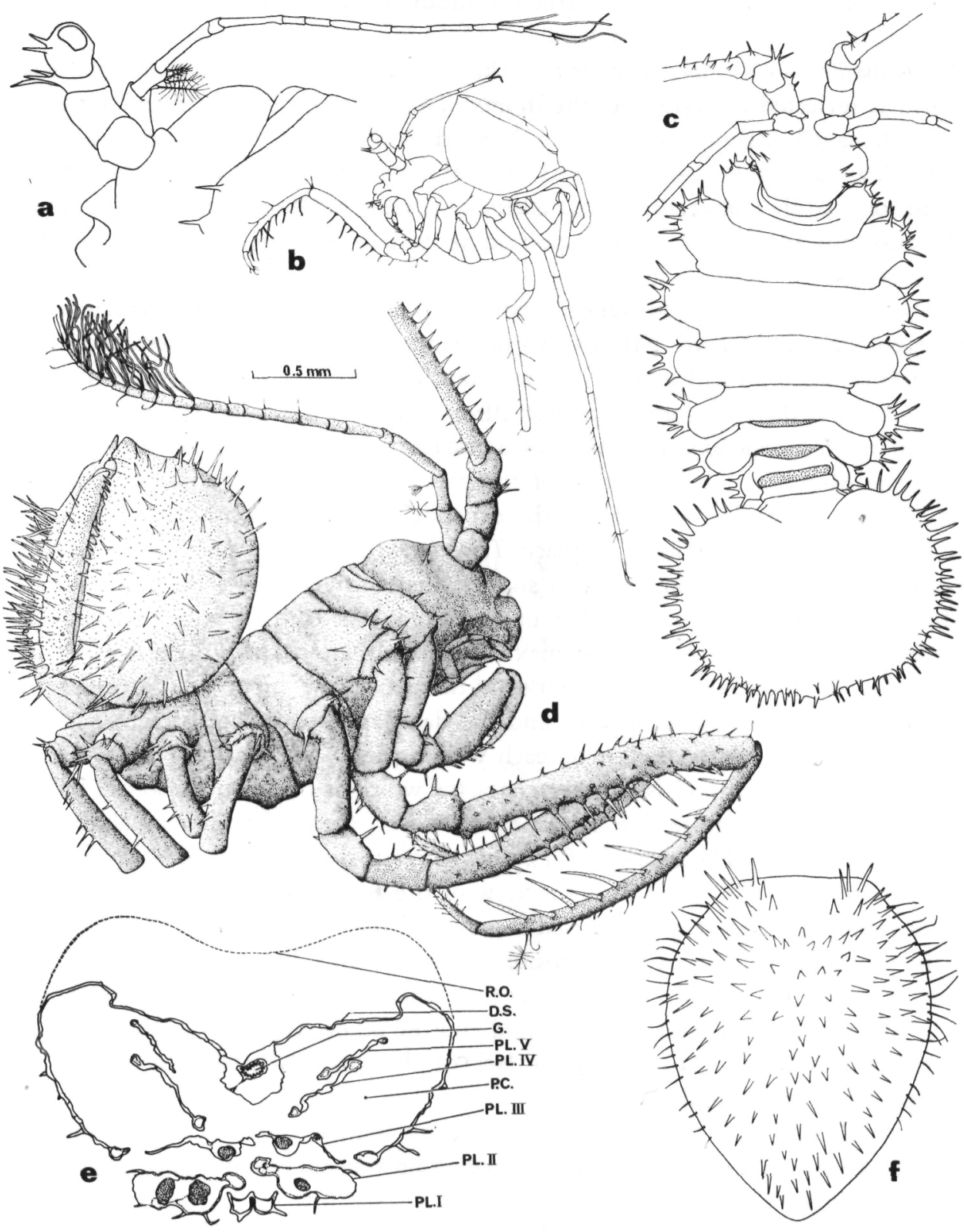

Fig. 1. Thylakogaster peterpauli n. sp. a, antennula and base of antenna, lateral view, preparatory female (USNM); b, body showing pereopodal proportions, lateral view, manca (ZMUC); c, body with pleon laid back, dorsal view, copulatory male; d, body, lateral view, copulatory male, holotype; e, pleotelson, cross-section, copulatory male (R.O. - restored outline, D.S. - dorsal surface, G. gut, P.C. - branchial cavity, remaining abbreviations refer to pleopods); f, pleopod II, ventral view, preparatory female. 
Derivation of name. --- Thylakogaster (masculine) is taken from the Greek words thylakos which can be construed to mean "balloon" and gaster which means "belly".

Discussion. - Thylakogaster is best characterized by its huge, bulbous abdomen which is reflected forward over the thorax. This abdomen is fragile and is usually badly damaged or completely missing. Nevertheless, some of the equatorial Atlantic individuals are quite well preserved. The finding of these specimens brought to mind some badly damaged material taken some years before off Bermuda (Atlantis II cruise no. 24), which on reinspection proved to be a separate species of the same genus.

The robust, raptorial appearance of pereopods II and III contrasting with ambulatory pereopods IV thru VII, the form of the spines on the molar process, a disproportionately small epipod on the maxilliped, and the ventral position of the uropods are additional unique features. Munna globicauda Vanhöffen, 1914, shows a similar, but independently derived (see discussion below comparing Tbylakogaster with the Munnidae) modification of the pleon, though it is not as pronouced as on Thylakogaster. The function of the expanded, erected pleon is not clear.

At present it is difficult to place Thylakogaster within any of the existing families. The cephalon and pereon suggest that the genus is a derivative of the Munnidae, but there are a number of characters that conflict with the diagnosis of that family: all segments of the maxillipedal palp are narrow, the antennula has many flagellar aesthetascs and segments, the subchelate hinge on pereopod I is between the carpus and propodus, and the dactylar claw, where present is single except for second vestigial claw on each walking leg.

The unjointed uropod is another character which is common to both Thylakogaster and the Munnidae (i.e. Munna). However, their uropods may actually be basically different. The uropod of Thylakogaster is distally bilobed; each of these lobes is supplied with setae. It is the view of the authors that at least one of these lobes represents a reduced and fused ramus, and that the main part of the uropod is the protopod. In Munna, the opposite situation obtains. From the variety of forms that appear in that family it is obvious that when an unjointed uropod is present it is one of the distal rami, the protopod and the other ramus having been lost. In fact, Menzies (1962: 31) makes the lack of the uropodal peduncle part of the diagnosis of the Munnidae.

A number of the above characters, the antennula, the subchelate hinge of pereopod I in particular, plus the tiny uropod prevent inclusion of this genus into the Antiasidac.

The Pleurogoniidae share with Thylakogaster the sagittate first pleopod, but there are differences between the pleopods of the two groups that may be basic. Spines occur on the ventral surface of pleopod $I$ in $T$ 'bylakogaster, and the appendage is very curved in lateral view, while on the Pleurogoniidae its ventral surface is generally flat and smooth. Additional conflicts with pleurogoniid characters are the very deep body, the short third article of the antenna, and the many segments 
and aesthetascs of the flagellum of the antennula. The previous arguments concerning the uropods also apply here.

The remaining family to which Thylakogaster could possibly belong is the Dendrotionidae. Nevertheless, one is hard pressed to find points of similarity. One outstanding character is again the antennula. This limb on $T$. peterpauli $\mathrm{n}$. sp. fits the diagnosis of the Dendrotionidae (Wolff, 1962: 64); the antennular peduncle of $T$. lobotourus $n$. sp. does not. One can find examples of the former type of antennula among members of the Janiridae, a basal group for a number of parasellote families. Possibly the antennula with many aesthetascs and articles, with article four being short, and articles three and five being longer, identifies retention of a primitive paraselloid character, rather than familial affinity. The spininess suggests affinity with the Dendrotionidae, yet the tiny uropod and the cephalon being recessed into the first pereonite are very different and suggest that any relationship with the dendrotionids is suprafamilial.

For all these reasons it is preferable to leave the familial designation for Thylakogaster temporarily undecided.

\section{Thylakogaster peterpauli new species (figs. 1,2)}

Holotype: Copulatory male (USNM 141465) from station 156.

Paratypes:

manca
juvenile male
copulatory male
preparatory female
preparatory female
copulatory male
copulatory male
manca

deposition

USNM 141467

USNM 141467

USNM 141467

USNM 141466

ZMUC

ZMUC

ZMUC

ZMUC station

155

155

155

156

156

156

155

155

Additional material: Station $155-47$ individuals; Station $156-78$ individuals.

Distribution: Equatorial Atlantic; WHOI benthic station 155: $00^{\circ} 03^{\prime} \mathrm{S} 27^{\circ} 48^{\prime} \mathrm{W}, 3730$ to 3783 meters; WHOI benthic station 156: $00^{\circ} 46^{\prime} \mathrm{S} 29^{\circ} 28^{\prime} \mathrm{W}, 3459$ meters.

Diagnosis. - Antennula of copulatory male (fig. 1d) rather slender, with 18-24 articles; articles 12-16 with median length to width ratio of 1.7 , range 1.5 to 1.8 ; aesthetascs begin on article 12 , with 2 or 3 per article; article 3 of antennula 1.7 times length of article 2; article 4 approximately one third length of article 2. Uropod (fig. 2r) with distomedial corner not enlarged into lobe; anterior side just adjacent to insertion not swollen, though enlarged somewhat close to distolateral corner. Body (fig. 1d) flexed so that pleotelson lies only above last five pereonites. Pleotelson rounded, tip not distinctly set off from main lateral lobes. 


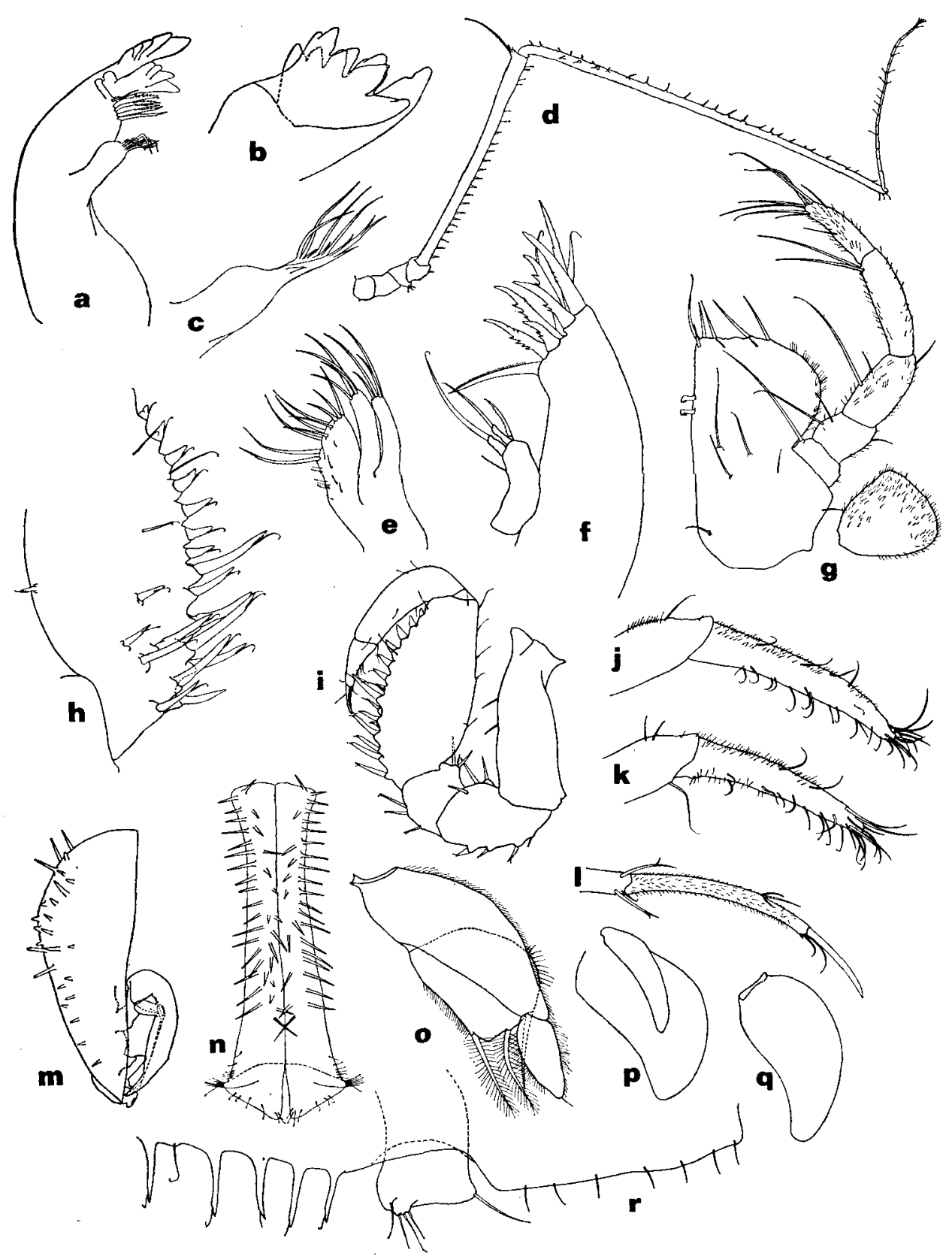

Fig. 2. Thylakogaster peterpauli n. sp. a-c, left mandible (a, entire mandible, dorsal view; $b$, incisor process and lacinia mobilis; $c$, molar process); d, antenna, holotype; e, maxilla; $f$ maxillula; $g$, maxilliped with detached epipod; $h$, carpus of pereopod I, medial view, preparatory female; $i$, pereopod I, lateral view, copulatory male; $j$, dactylus, pereopod I, holotype; $k$, dactylus, pereopod II, holotype; 1, dactylus, pereopod VI, manca (ZMUC); m-q, pleopods, copulatory male (m, pleopod II; n, pleopod I; o, pleopod III; p, pleopod IV; q, pleopod V); r, left uropod, lateral view, holotype. 
No pronounced size difference between aduit males and females, tergal width of copulatory males and preparatory females approximately $1.5 \mathrm{~mm}$.

Additional description, copulatory male. - Pereonites (fig. 1c) have the following dimensions:

$\begin{array}{ccc}\text { pereonite } & \begin{array}{c}\text { width/midsagittal } \\ \text { length ratio }\end{array} & \begin{array}{c}\text { width with } \\ \text { respect to pereonite } 3\end{array} \\ 1 & 4.3 & 0.62 \\ 2 & 5.0 & 0.92 \\ 3 & 4.7 & 1.00 \\ 4 & 4.4 & 0.91 \\ 5 & 5.5 & 0.79 \\ 6 & 7.9 & 0.67 \\ 7 & 8.3 & 0.44\end{array}$

Antenna (fig. 2d): peduncle with 4 short proximal articles and 2 very long distal articles. Article 3 with anteromedial bump having three setae. Article 5 three times length of first four articles. Article 6 longer than article 5, ratio 1.7. Flagellum 0.48 length of article 6 , with about 17 articles.

Mandible (figs. 2a-2c) without palp. Left incisor process with 5 teeth; posterior tooth largest; teeth decreasing in size anteriorly. Lacinia mobilis broad; insertion protruding dorsally from incisor process; with 5 teeth; most dorsal tooth minute with little separation from adjacent tooth. Molar tuft consisting of 5 long spines and 4 short spines at their bases; most posterior long spine bifid; 5 saw-bristles in row and one smooth seta next to lacinia mobilis.

Maxilliped (fig. $2 \mathrm{~g}$ ): basis 1.8 times longer than wide, with two receptacula. Palp narrow, gradually tapering; basal segment only 0.4 width of basis, distal segment 0.47 width of basal segment. Epipod 1.1 times wider than long; width 0.76 basis width; finely setose.

Pereopod I (figs. $2 \mathrm{~h}, 2 \mathrm{i}$ ) robust and strongly subchelate. Strong unequally bifid setae of varying length on basis through carpus. Carpus with most setae, having 14-16 setae on ventral margin and 6-8 short and stout setae distal to large central seta. Dactylus 0.45 length of propodus; tip of dactylar claw reaching to proximal quarter of carpus when folded against it. Carpus 2.0 times longer than wide, slightly longer than basis. Basis 2.8 times longer than wide.

Pereopod II (fig. 1d) very long, roughly 2 times length of cephalon-pereon. Limb subchelate, with dactylus and propodus together acting as movable finger; when folded back, tip of dactylus at level of base of merus. Dactylus short, 0.16 length of propodus, without major setae, with short claw. Propodus curved, long, slender, being 19 times longer than wide. Both carpus and propodus with numerous setae arising from short protuberances of limb segment wall; setae of occlusive margin on carpus and lateral and medial side of propodus particularly large. Basis 3.1 times longer than wide.

Pereopod III (fig. 1d) similar to pereopod II but lacking dactylar claw, possibly due to damage. 
Pereopods IV through VII broken off all adults; basis of each narrower than basis of pereopod II, respectively $0.76,0.65,0.65,0.65$. (On a manca (fig. $1 \mathrm{~b}$ ) pereopod V intact: very long, slender, 2.1 times length of cephalon-pereon.)

Pleopod I (fig. 2n) long, 6.1 times longer than narrowest width; narrowest 0.3 length from base, becoming gradually wider distally; widest point 0.09 length from distal where width is 0.34 total length. In side view limb convex ventrally, with flattened tip at obtuse angle to proximal part of pleopod. Fine setae occur on ventrolateral edge of distal end, having highest density on laterally projecting tips.

Pleopod II (fig. 2m) 3.1 times longer than wide. Slender spines on rounded lateral edge. Stylet stout, less than half length of pleopod.

Uropod (fig. 2r) truncate on distal end, with setae on corners.

Preparatory female, characters different from male. - Antennula (fig. 1a) shorter than body, not as robust as male. Third article 1.9 times length of article 2 . Fourth article 0.44 times length of article 2.

Pleopod II (fig. If) 1.3 times longer than wide. Fine setae on lateral margins. Many long slender spines on ventral surface.

Developing oostegites: anlagen appear as raised cuticular shelves on sternites adjacent and medial to coxae of pereonites 1 to 5 .

Remarks. - The copulatory male of this species is most easily recognized by the somewhat narrow antennula with no greater than three aesthetascs per article. Both sexes lack an enlarged lobe on the uropod and may also be recognized by the degree of flexure of the body and the rounded pleotelson.

Derivation of name. - This species was collected near St. Peter and St. Paul Rocks, hence the name peterpauli.

\section{Thylakogaster majusculus new species (fig. 3)}

Holotype: Copulatory male (USNM 141468) from station 259.

Paratypes: All paratypes from station 259: copulatory male (USNM 141470), brooding female (USNM 141469), preparatory female (USNM 141469), copulatory male (7MUC), preparatory female (ZMUC).

Additional material: Station $247-21$ individuals, most in poor condition; Station $259-130$ individuals.

Distribution: Argentine Basin in southwestern Atlantic; WHOI benthic station 247: $43^{\circ} 33^{\prime} \mathrm{G}$ $48^{\circ} 58^{\prime} \mathrm{W}, 5208-5223$ meters; WHOI benthic station 259: $37^{\circ} 13^{\prime} \mathrm{S} 52^{\circ} 45^{\prime} \mathrm{W}, 3305-3317$ meters.

Diagnosis. - Antennula of copulatory male (fig. 3c) more robust than in other species, with 24-28 articles; articles 12-16 with median length to width ratio of 1.0 , range 0.8 to 1.2 (composite of 5 individuals); articles 5 to 12 may be wider than article 4 , giving antennula expanded appearance in that region; aesthetascs begin on article 5, appearing 3-8 per article; third article 0.9 length of article 2; fourth article 0.2 length of article 2. Uropod (fig. $3 \mathrm{~h}$ ) with distomedial corner enlarged into projecting lobe not as large as in $T$. lobotourus; anterior side just adjacent to insertion somewhat swollen. Body (fig. 3c) highly flexed so that pleotelson lies above entire pereon; as a resuit, dorsal pleonal concavity (fig. 3b) (which serves to accomodate the convexity of the pereon to which it is appressed) 


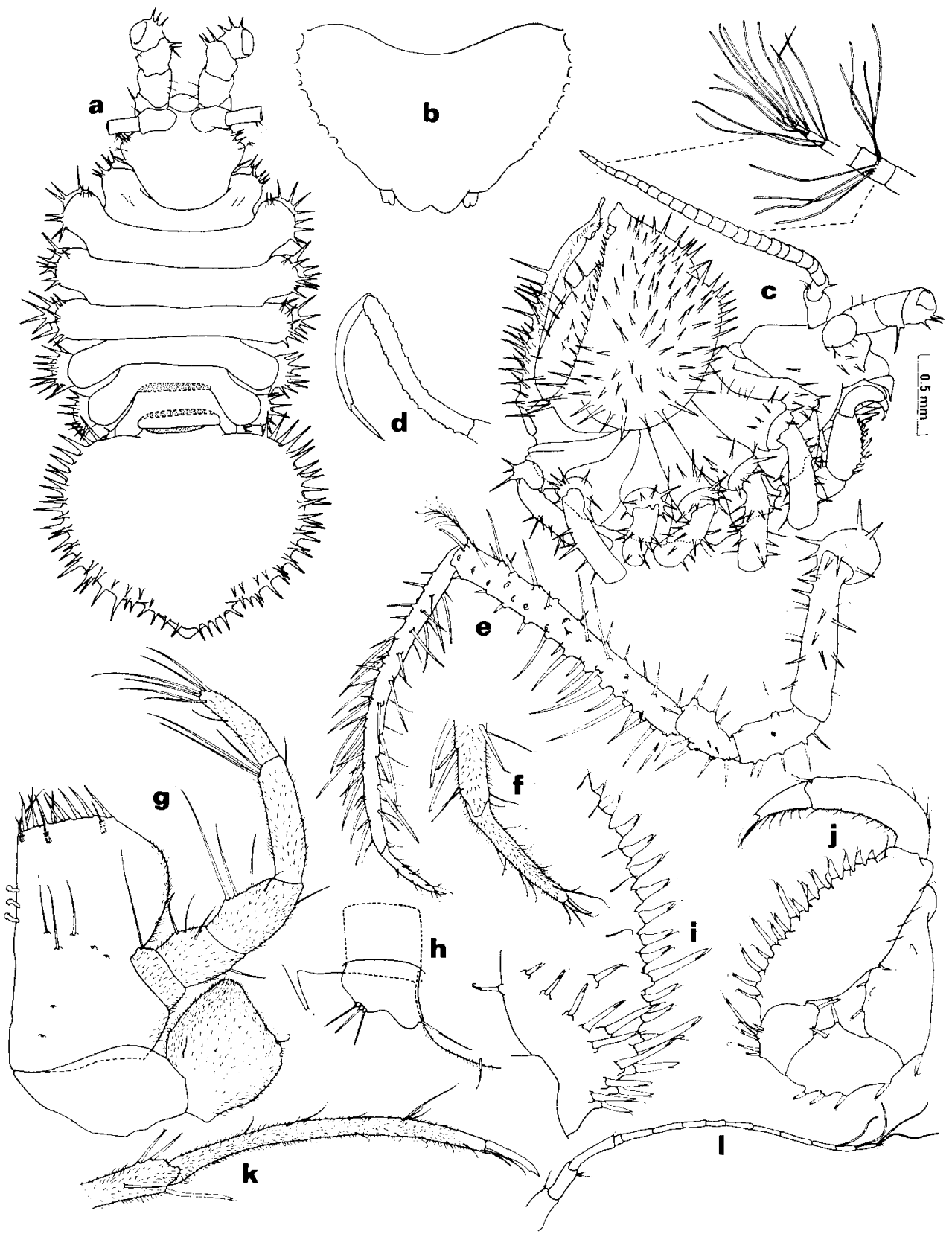

Fig. 3. Thylakogaster majuscutus n. sp. a, body, dorsal view, copulatory male; b, outline of pleotelson, posterior view; c, body, lateral view with aesthetascs omitted on antennula, holotype; d-f, pereopod III, copulatory male ( $\mathrm{d}$, outline of carpus, propodus, and dactylus in dorsal view; e, entire limb, lateral view; f, dactylus); $g$, maxilliped, ventral view; h, left uropod, lateral view; $i-j$, pereopod I (i, carpus, medial view, preparatory female; $j$, entire limb, lateral view, holotype); $k$, dactylus of pereopod V, lateral view, copulatory male; 1 , antennula, lateral view, preparatory female. 
broader than in $T$. peterpauli, and dorsolateral convexities on pleotelson more acutely rounded; body more spinose than in $T$. peterpauli. Tip of pleotelson (fig. 3a) more produced, more distinctly set off from main lateral lobes of pleotelson. Size difference between males and females pronounced, width of tergum of pereonite 3 of copulatory males approximately $1.3-1.6 \mathrm{~mm}$ ( 6 individuals measured), of preparatory females approximately $2.0 \mathrm{~mm}$.

Additional description, differences from $T$. peterpauli. - Maxilliped (fig. $3 \mathrm{~g}$ ) on large adults with three coupling hooks. Epipod longer than wide, distally acute.

Pereopod I (fig. $3 \mathrm{j}$ ) carpus with 7 to 9 setae on ventral margin distal to large centrally placed setae. Adult females with more carpal setae (fig. 3i) than copulatory males.

Pereopod III (fig. 3e) of premolt copulatory male (see below) with dactylar claw 0.20 length of dactylus. Carpus and propodus (fig. 3d) laterally convex in dorsal view. Fine setae on limb surface only on two distal segments, on propodus extending proximally from segment tip as far as fourth simple seta on occlusive margin.

Pereopods IV to VII broken off of most adults; basis of each 0.82 narrower than basis of pereopod II, being proportionately less slender than in $T$. peterpauli. Pereopod V of one premolt copulatory male intact, length 2.4 times cephalonpereon length, proportions of limb segments similar to manca; claw 0.24 length of dactylus (fig. 3k).

Remarks. - Thylakogaster majusculus has the deepest (5223 meters) and broadest (1918 meters) depth range of any of the Thylakogaster now known. This species also has the greatest size, the largest individuals (females) being around $2 \mathrm{~mm}$ wide and over $3 \mathrm{~mm}$ in cephalon-pereon length. This species is easily differentiated from $T$. peterpauli by the form of the male antennula, the shape of the uropod, and the overall appearance of the body, including the pleotelson.

In this species, at least, the male appears copulatory in the last two instars. A premolt male was found that had a morphologically functional stylet; the old stylet and the new structure developing beneath the cuticle were identical. This premolt male was one size class below the largest males in the sample. Other males of this smaller size class were also morphologically copulatory. This evidence suggests that in this genus males breed over an extended period of time, during which individuals continue to grow.

Derivation of name. - Majusculus, meaning "somewhat larger", refers to the size of adults of this species which is greater than any other Thylakogaster.

\section{Thylakogaster lobotourus new species (fig. 4)}

Holotype: Copulatory male (USNM 141471) from station 118.

Paratypes: Immature female (USNM 141472) from station 118; 2 copulatory males (ZMUC) from station 118, two fragments.

Additional material: Station $118-14$ individuals or fragments, most in poor condition; Station $119-1$ individual, pleotelson only. 
Distribution: Bermuda slope, seven miles southeast of northern tip of the Bermuda Islands; WHOI benthic station 118: $32^{\circ} 19^{\prime} \mathrm{N} 64^{\circ} 32^{\prime} \mathrm{W}, 1135$ to 1153 meters; WHOI benthic station 119: $32^{\circ} 16^{\prime} \mathrm{N} 64^{\circ} 32^{\prime} \mathrm{W}, 2095$ to 2223 meters.

Diagnosis. - Antennula of copulatory male (fig. 4a) robust, with about 26 articles; articles 12-16 with median length to width ratio of 1.3 , range 1.2 to 1.5 ; aesthetascs begin on article 5, with 2 to 7 per article; article 3 of antennula same length as article 2; article 4 less than half as long as article 2. Uropod (fig. 4e)

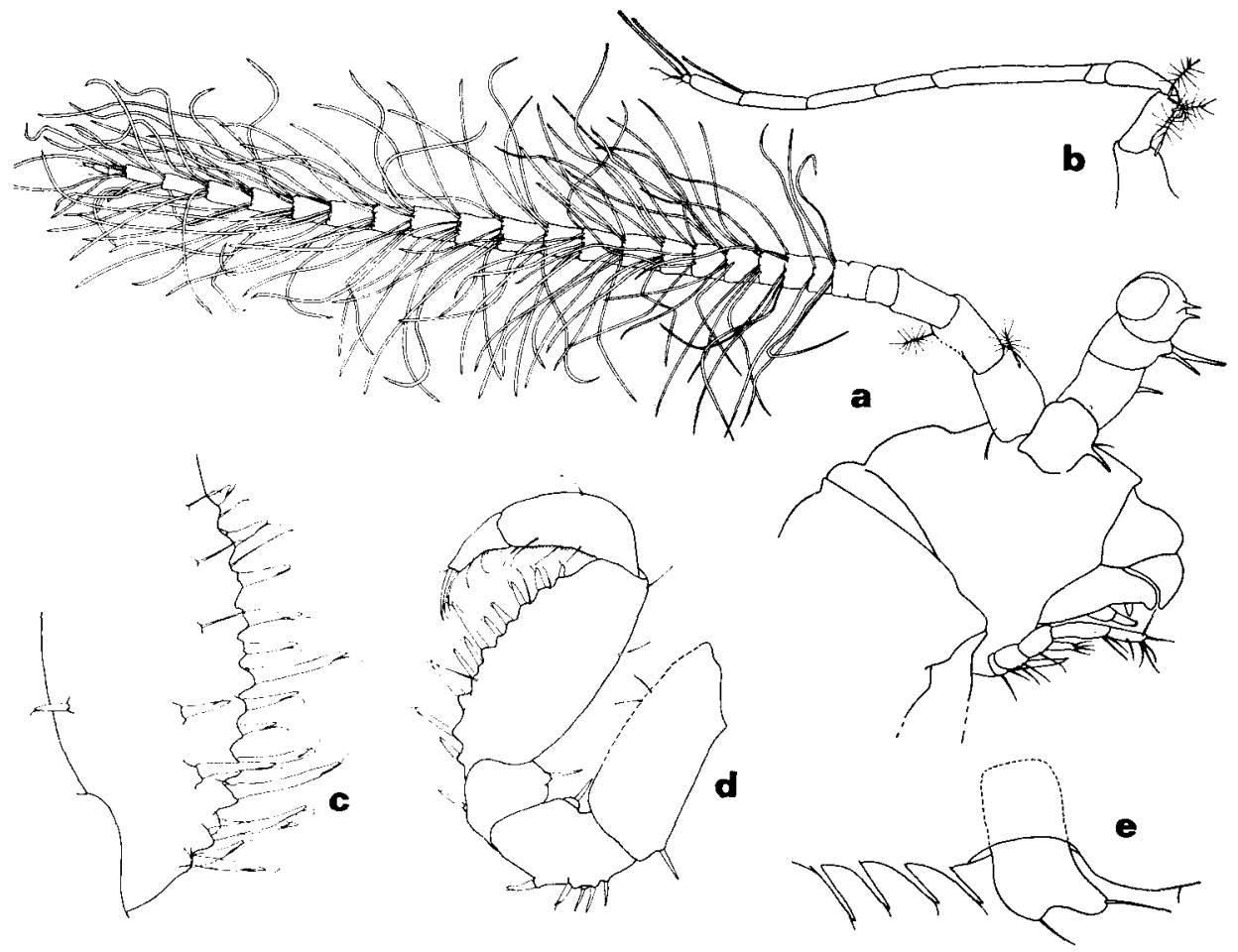

Fig. 4. Thylakogaster lobotonrus n. sp. a, cephalon with antennula and base of antenna, lateral view, holotype, copulatory male; b, antennula, lateral view, juvenile female (USNM 141472); c-d, pereopod I, juvenile female ( $c$, carpus, medial view; $d$, entire limb, lateral view); e, left uropod, lateral view, holotype.

with distomedial corner enlarged into projecting lobe; anterior side adjacent to insertion not swollen. Size differences between males and females pronounced; copulatory males smaller than preparatory females, with pereonite 3 tergal width 1.1 to $1.2 \mathrm{~mm}$.

Additional description, differences of immature female from Thylakogaster peterpauli. - Antennula (fig. 4b): third article 0.94 times length of article 2; fourth article 0.25 times length of article 2 .

Pereopod I (figs. 4c, 4d) : carpus with about 17 strong unequally bifid setae, 6 on medial surface, 11 setae in row on ventral margin, with only 5 short setae distal to large centrally positioned setae in ventral series. 
Remarks. - $T$. lobotourus is fairly similar to $T$. majusculus. However, in spite of the poor condition of the material from Bermuda, there are observable differences that justify maintaining this form as a separate species. The antennula of the copulatory male is less robust and tapers evenly after the fourth article. The uropods of this species have a more pronounced distomedial lobe and are not swollen on the anterior side. In view of the completely ambulatory habitus of Thylagokaster, the great distance that separates $T$. lobotourus and T. majusculus and the intervention of the morphologically distinct $T$. peterpauli, the conclusion that $T$. lobotourus is biologically distinct from $T$. majusculus is a reasonable one.

Derivation of name. - Lobotourus refers to the enlarged lobe on the uropod of this species. Lobos means "lobe", and ourus is latinized Greek for "tail".

\section{Abyssaranea new genus}

Type species. - Abyssaraned rupis n. sp. (figs. 5, 6).

Diagnosis. - Cephalon without eyes or lateral projections, relatively small compared to body, rounded, much narrower than pereonite 1. Body deep, ovate, almost as deep as broad. Pereonite 1 large, twice as long as succeeding segments. Dorsally, pereonites 5 and 6 strongly reduced and pereonite 7 absent; pereon more normally developed ventrally; as a result, origin of pleotelson tipped upward and base of pereopod VI folded under pleotelson ventrolaterally. Pleotelson large (longer than pereon), ovoid, very deep, being taller than long in side view. Antennula of copulatory male same length as body, with many aesthetascs and articles; antennula of preparatory female approximately half body length, with fewer articles and very few aesthetascs. Antenna about two-thirds length of body, with 4 short proximal articles, long fifth and sixth. Mandibular palp large; molar process cylindrical, truncate, with row of setae bordering posterior margin of occlusive surfaces. Maxilliped: palp with articles 2 and 3 distinctly broader than others, nearly as wide as basal endite; distolateral edge of article 4 rounded in shape, not produced; epipod rounded distally. Pereopod I robust, subchelate, with major hinge between enlarged carpus and propodus. Pereopods II-VI moderately long, about as long as body or longer, ambulatory, similar in form. Pereopod VII completely absent. All pereopods with single dactylar claw. Pleopod I of copulatory male broadest at base, gradually tapering distally; tip evenly rounded with arcuate row of setae. Uropod with only single article, inserting close to posterior of pleotelson.

Derivation of name. --.-Abyssaranea (feminine) means "abyssal spider" in Latin, referring to the peculiar morphology of this genus.

Remarks. - The compact, arachnid-like appearance of the body. and the tiny, uniramous, unsegmented uropod make Abyssaranea immediately recognizable. There can be no confusion between this genus and Munella. The single species of Abyssaranea has pronounced sexual dimorphism, a feature which may ultimately prove to be of generic significance. 


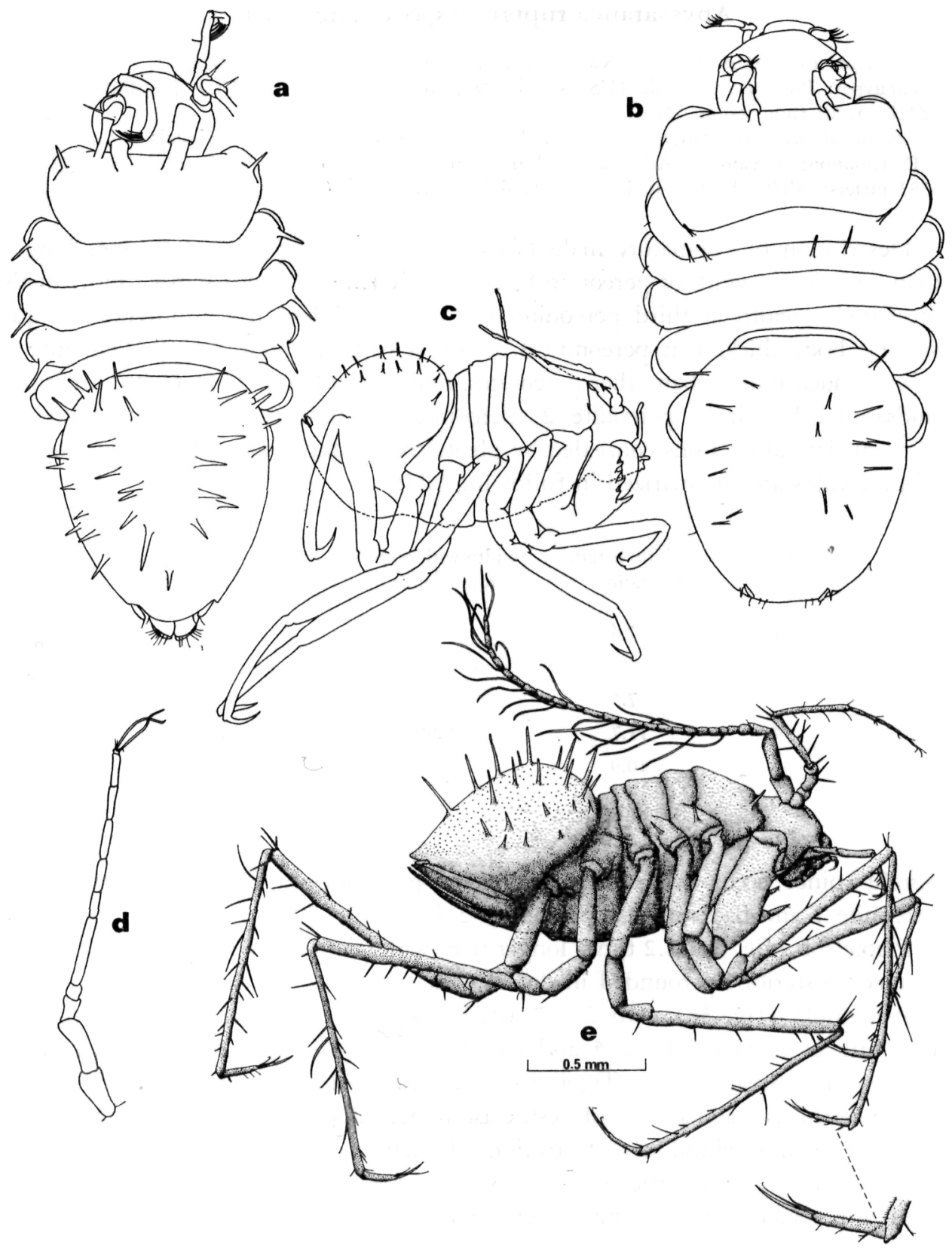

Fig. 5. Abyssaranea rupis n. sp. a, body, dorsal view, copulatory male, holotype; b-c, body, preparatory female (USNM 141474) (b, dorsal view; c, lateral view); d, antenna, preparatory female; e, body, lateral view, holotype. 


\section{Abyssaranea rupis new species (fig. 5, 6)}

Holotype: Copulatory male (USNM 141473) from station 156.

Paratypes: Preparatory female (USNM 141474), copulatory male (ZMUC), preparatory female (ZMUC), all from station 156.

Additional material: Station 155 - 2 individuals; Station $156-10$ individuals.

Distribution: Equatorial Atlantic; WHOI benthic station 155: $00^{\circ} 03^{\prime} \mathrm{S} 27^{\circ} 48^{\prime} \mathrm{W}, 3730$ to 3783 meters; WHOI benthic station 156: $00^{\circ} 46^{\prime} \mathrm{S} 29^{\circ} 28^{\prime} \mathrm{W}, 3459$ meters.

Description of copulatory male (figs. 5a, 5e). - Cephalon 1.5 times longer than wide, 0.58 width of pereonite 1 . Total body length $1.5-1.7 \mathrm{~mm}$ (2 individuals measured), width at third pereonite 0.47-0.49 total length ( 2 individuals measured); body thickest at pereonite 3, depth 0.39 times body length. Pereonite 1 robust, much longer than other pereonites, midsagittal length 0.41 width, 2.1 times midsagittal length of pereonite 2. Pereonite 6 visible on dorsum as flattened crescent; lateral portions concealed by pleotelson in dorsal view. Size relationships of pereonites are summarized in following table.

$\begin{array}{cccc}\text { pereonite } & \begin{array}{c}\text { width/length } \\ \text { ratio }\end{array} & \begin{array}{c}\text { width with respect } \\ \text { to pereonite } 3\end{array} & \begin{array}{c}\text { length with respect } \\ \text { to pereonite 1 }\end{array} \\ 1 & 2.4 & 0.78 & 1.00 \\ 2 & 6.2 & 0.93 & 0.47 \\ 3 & 7.5 & 1.00 & 0.44 \\ 4 & 11.7 & 0.99 & 0.26 \\ 5 & 10.9 & 0.92 & 0.26 \\ 6 & 17.0 & 0.80 & 0.15\end{array}$

Single spines occur on lateral margins of pereonites 1-4, angling forward on pereonite 1 and backward on pereonites 2-4.

Pleotelson (fig. 5a) 1.2 times longer than wide, with many long spines on dorsal surface; posterior tip rounded in dorsal view.

Antennula (fig. 5e) with 26-27 articles; second article 1.7 times longer than first article; third article 0.75 and fourth article 0.42 times length of article 2; article 5 not distinct from flagellar articles; each article beyond the fifth having single aesthetasc; attachment of aesthetasc rotated approximately $90^{\circ}$ from aesthetascs before and behind so that positions alternate.

Antenna (fig. 5e): articles 5 and 6 long, accounting for 28 and 32 percent of total appendage length respectively; flagellum 0.9 length of article 6 , with 7 articles.

Mandibular incisor process (figs. 6a-6c) with 5 teeth. Lacinia mobilis with 5 teeth; anterior tooth small bump on side of second tooth; second tooth very sharp, especially long. Three broad saw-tooth setae separated from row of 4 tubercles by shallow depression; posterior setae stronger than others. Palp extremely long, one fourth body length, 2.0 times length of mandible body; with tendency in 


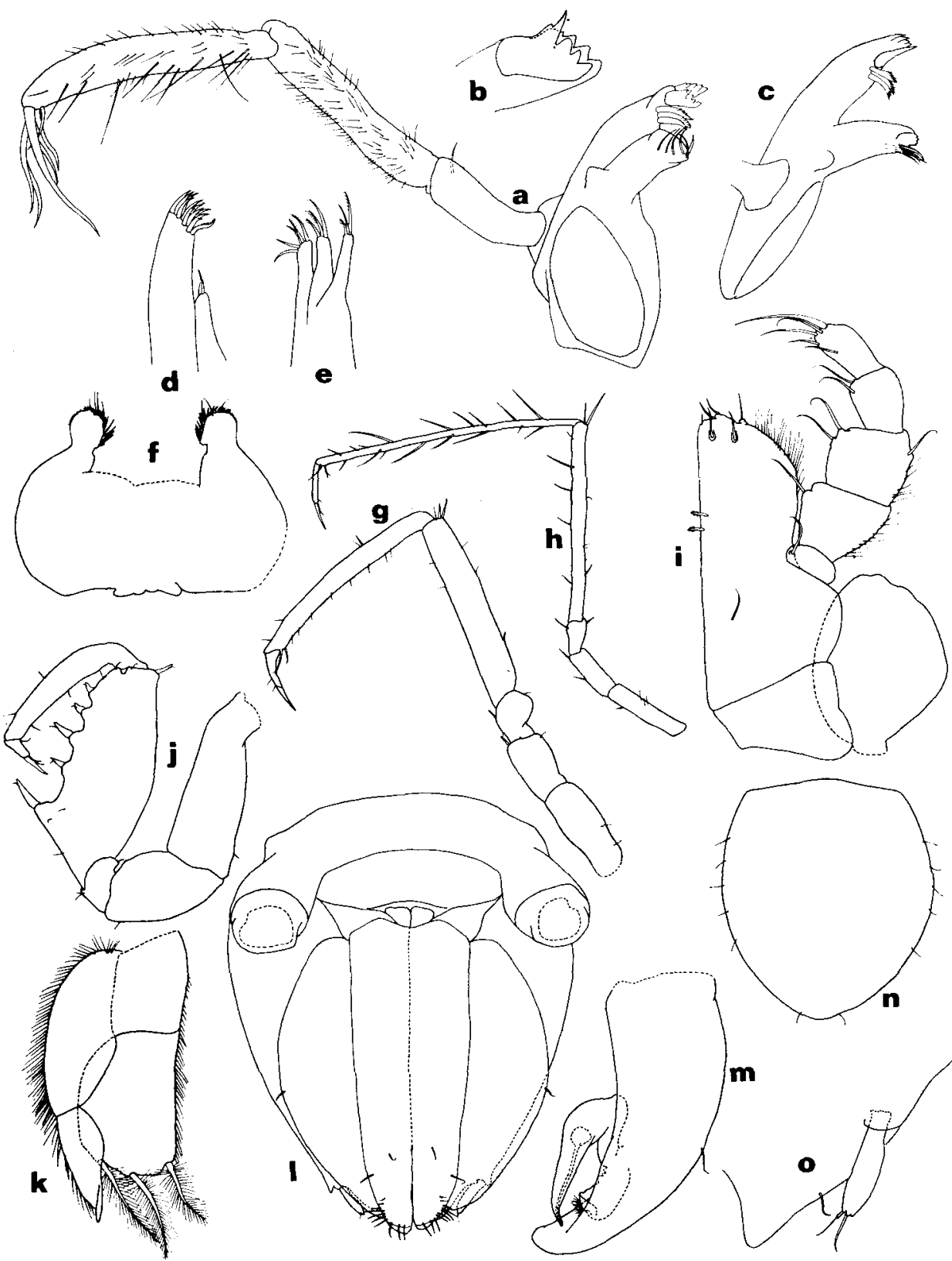

Fig. 6. Abyssaranea rupis n. sp. a-c, left mandible (a, entire mandible, dorsal view; b, incisor process and lacinia mobilis; c, mandible body, rotated to show profile of molar process); d, maxillula; e. maxilla; f, paragnaths; g, pereopod VI, preparatory female (USNM 141474); $h$, pereopod VI, copulatory male, holotype; i, maxilliped; $\mathfrak{j}$, pereopod I, lateral view; $k$, pleopod III; 1 , pereonites 6-7 and pleotelson, ventral view, showing arrangement of segments and pleopod I, holotype; $\mathrm{m}$, pleopod II, holotype; o, right uropod, lateral view. 
preserved specimens to be held vertically in front of cephalon; segments 2 and 3 with many fine setae; tip with curved row of 6 stronger setae.

Maxilliped (fig. 6i) with two receptacula. Coxa much longer laterally than medially. Widths of palp segments 2.5 with respect to segment 1 are $1.6,1.6$, $0.95,0.65$, respectively; second and third segments 0.6 width of basis, 0.84 width of endite. Epipod rounded, 1.4 times longer than wide, 0.61 length of basis.

Pereopod I (fig. $6 \mathrm{j}$ ): basis roughly 1.2 times longer than those of posterior pereopods. Carpus with 5 strong setae opposing propodus and dactylus; single strong seta on distal end of dorsal margin; carpus large, 0.35 body length, 1.3 times longer than basis, 2.2 times longer than wide. Dactylus movably articulated with propodus, with single claw; with subchela closed and dactylus extended, dactylus and propodus reach 0.85 length of carpus.

Pereopods II and III (fig. 5e) 1.5 times longer than body; pereopods IV-VI 1.6 body length; all ambulatory pereopods slight, with numerous long thin setae and elongate dactylar claws. Pereopod VI (fig. $6 \mathrm{~h}$ ): carpus and propodus relatively long, comprising 30 and 39 percent of total pereopod length respectively. Pereopods II-V similarily developed.

Pleopod I (fig. 61) 2.7 times longer than wide.

Pleopod II (fig. $6 \mathrm{~m}$ ) with short stylet, 0.46 length of pleopod.

Uropod (fig. 60) 4.2 times longer than wide, arising near tip of pleotelson, and normally folded against it.

Preparatory female (figs. 5b, 5c), major differences from adult male. Larger, total length being around $2.1 \mathrm{~mm}$; width at pereonite 30.51 length; body half as thick at pereonite 3 as long.

No large spines on pereonites 1-4; a few thin spines may occur on dorsal surface of pereon.

Pleotelson with numerous short thin spines; posterior tip more bluntly rounded in dorsal view.

Antennula (fig. 5d): third article 0.52 and fourth article 0.33 times length of article 1; article 5 greater than twice as long as next 5 articles; with only two aesthetascs, one each on 2 distal articles; distal article less than one fourth length of penultimate article; antennula with total of 11 articles.

Pereopods II-VI same length as body or slightly longer, robust, with setae much smaller than on male. Pereopod VI (fig. $6 \mathrm{~g}$ ) carpus and propodus comprise respectively 29 and 33 per cent of total pereopod length.

Pleopod II (fig. 6n) 1.2 times longer than wide; very convex ventrally; approximately 6 pairs of setae occur on lateral margins.

Remarks. - In this species sexual dimorphism is striking. The males are small, slight and long-limbed with the appearance of being extremely fragile. In contrast, the larger females are particularily sturdy-looking, muscular, and have shorter and stouter legs.

Derivation of name. - Rupis means "rock", referring to St. Peter and St. Paul Rocks. 


\section{Munella Bonnier, 1896}

Type species. - Munella danteci Bonnier, 1896.

Diagnosis. - Cephalon without eyes, of normal size, laterally angular or curved. Body normally shaped, somewhat compressed anteroposteriorly, with large setae on all dorsal and lateral surfaces. Pereonite 7 reduced, but present dorsally as well as ventrally. Pleotelson pyriform, much shorter than pereon, not inflated. Antennula of copulatory male less than half body length, with 11 or 12 articles, last 6-7 articles with aesthetascs; antennula of mature female roughly one-third body length, with around 8 articles, 3 distal articles with single aesthetasc. Mandibular palp large; molar process flattened and blade-shaped, armed distally with densely spaced spines. Maxillipedal palp with distomedial edge of article 4 produced into acute angle; articles 2 and 3 not enlarged, much narrower than basal endite; tip of epipodite pointed. Pereopod I robust, subchelate, with major hinge between carpus and propodus, with single dactylar claw. Pereopods I-VI with coxae visible in dorsal view; pereopods II-VI as long as body or longer, ambulatory with two dactylar claws each; pereopod VII completely absent. Pleopod I of copulatory male widest at base; tip slightly flaring; all margins supplied with setae. Uropods uniramous, two-segmented; first segment approximately same length as second segment; situated one third length of pleotelson from posterior tip.

Remarks. - This is the first diagnosis of Munella. Bonnier (1896) merely described the single individual in his possession as a species, without indicating those features of generic significance. The form of the above diagnosis was constructed in a fashion that would allow comparison to Abysiaranea. Note that Munella is more normally shaped than Abyssaraned. Other obvious diagnostic features are the presence of the seventh pereonite dorsally and a biarticulate uropod. Abyssarmea has neither character.

Munella and Abyssaranea have similarities that are worth mentioning. Most significantly, both have an appendageless and reduced pereonite 7 . Additionally, the following list of characters apply to both genera: the eyes are absent; the body is ovate and is compressed lengthwise; all coxae are visible in dorsal view; the antennules have many articles and aesthetascs in males, fewer in females; pereopod I is large, robust and subchelate, and has the major hinge between the carpus and propodus; the uropods are small and uniramous. This unique combination of characters demonstrates that Munella and Abyssaranea are closely related.

Wolff (1962: 64) places Munella in the Dendrotionidae on the basis of similarities of the antennula, maxilliped, and the number of claws on the pereopods. As mentioned above (p. 51), the form of the antennula reflects retention of a basic paraselloid character. The uropods of Munella and Abyssaranea in no way resemble those of other Dendrotionidae, being small and uniramous instead of large and biramous. The uropods are fairly important characters in this case. In order to avoid complication, perhaps unnaturally, of the concept of the Dendrotionidae, it seems best to exclude these two genera from that family. 
On the other hand, Munella and Abyssaranea do not fit into the families that have small uropods, i.e. the Pleurogoniidae and the Munnidae, due to differences in the antennulae, the antennae, the first pereopods and the number of claws on the pereopods. Thus, as the group represented by Munella and Abyssaranea becomes better known, it seems probable that a new family will be erected to receive them.

\section{Munella gayda new species (fig. 7)}

Holotype: Copulatory male (USNM 141475) from station 118, all pereopods missing and pleotelson damaged.

Paratype: Brooding female (USNM 141476) from station 118, all pereopods missing.

Additional material: Station $118-4$ individuals, all pereopods missing, with one being represented by cephalon only.

Distribution: Bermuda slope, seven miles southeast of northern tip of the Bermuda Islands; WHOI benthic station 118 : $32^{\circ} 19^{\prime} \mathrm{N} 64^{\circ} 32^{\prime} \mathrm{W}, 1135$ to 1153 meters.

Diagnosis. -- Pereon slightly longer than wide, ratio of width to length being 0.96. Major setae on body distributed as follows: cephalon with 1 pair laterally, one pair dorsally, plus additional setae of irregular size and placement; pereonites 1, 6 and 7 with one medially; pereonites $2-5$ with one pair medially; coxae of pereopods I-IV with two pairs each; coxae of pereopods V-VI with one; pleotelson with approximately three pairs dorsally, also with some laterally and posteriorly. Pleopod I with convex distal margin. Mandibular palp only 0.85 length of body of mandible.

Additional description, copulatory male (figs. 7c, 7d). - Length approximately $1.4 \mathrm{~mm}$. Of thoracic segments, pereonite 1 longest, pereonite 3 widest. Size relationships of pereonites summarized in following table.

$\begin{array}{cccc}\text { pereonite } & \begin{array}{c}\text { width/length } \\ \text { ratio }\end{array} & \begin{array}{c}\text { width with respect } \\ \text { to pereonite 3 }\end{array} & \begin{array}{c}\text { length with respect } \\ \text { to pereonite 1 }\end{array} \\ \mathbf{1} & 2.7 & 0.78 & 1.00 \\ \mathbf{2} & 4.7 & 0.93 & 0.68 \\ \mathbf{3} & 5.8 & 1.00 & 0.59 \\ \mathbf{4} & 6.0 & 0.95 & 0.55 \\ \mathbf{5} & 8.0 & 0.84 & 0.36 \\ 6 & 7.0 & 0.64 & 0.32\end{array}$

Pleon roughly 1.3 times longer than wide; in lateral view slightly domed anteriorly, flattened somewhat posteriorly.

Antennular articles 1, 2, 3 and 5 (figs. 7c, 7d) approximately same length; article 4 one third as long. Articles 5-12 each with single, medially attached aesthetasc.

Antenna (fig. 7d) with long thin setae on articles 4-6; fifth article 1.3 times longer than article 6; articles 5 and 6 together are 0.55 body length. Antenna of juvenile male (fig. 7 b) (only specimen with intact antenna) with 7 flagellar articles.

Pleopod I (fig. $7 \mathrm{~m}$ ) 4.2 times longer than wide. 


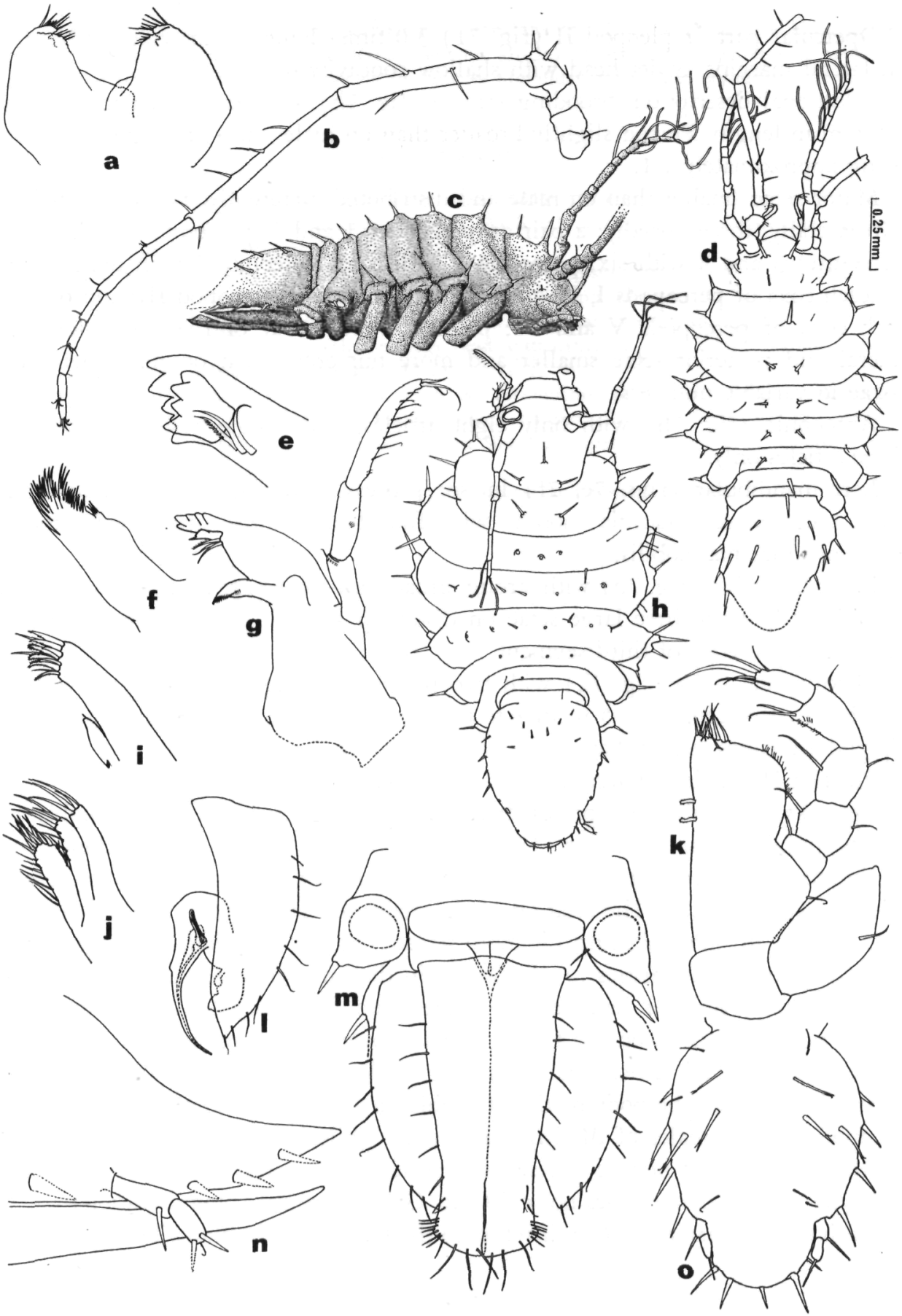

Fig. 7. Munella gayda n. sp. a, paragnaths; b, antenna, juvenile male; c-d, body, copulatory male, holotype ( $c$, lateral view; d, dorsal view); e-f, left mandible (e, incisor process, lacinia mobilis and 3 setae; $f$, molar process); g, right mandible, ventral view; $h$, body, brooding female (USNM 141476), dorsal view; i, maxillula; $j$, maxilla; $k$, entire maxilliped; l, pleopod II, holotype; m, pereonites 6-7 and pleotelson, ventral view, showing arrangement of segments and pleopod I, holotype; $n$, distal tip of pleotelson and left uropod, lateral view, paratype; o, pleotelson and uropods, juvenile male, dorsal view. 
Opercular part of pleopod II (fig. 71) 3.0 times longer than wide, with setae on lateral margins. Stylet head with shallow concavity on medial side.

Additional description, brooding female (fig. 7h). - Larger than male, body $1.6 \mathrm{~mm}$ in length. Pereon slightly broader than on male, ratio of length to width being approximately 1.1 .

Major setae smaller than on male and distributed differently: five on cephalon, two laterally, three dorsally; a pair on pereonites 1 and 6; pereonite 2 with three; pereonites 3 and 4 with six; pereonite 5 with four; pereonite 7 with none; three on each coxa of pereopods I, II, and VI; two on coxa of pereopod III; and one on each coxa of pereopods V and VI; pleotelson with four or five pairs dorsally; lateral and posterior setae smaller and more numerous than on male. Setae on coxae in variable numbers.

Antennula (fig. 7 h) with only eight articles, with single aesthetascs on last three articles only.

Left mandibular (figs. 7e, 7f) incisor process with five teeth; second tooth from end reduced. Lacinia mobilis with four teeth. Three strong saw bristles adjacent to lacinia mobilis.

Right mandible (fig. $7 \mathrm{~g}$ ) with strong, broad, saw-toothed seta in place of lacinia mobilis. Palp with three large setae on distal tip and long, fine setae in row on concave lateral edge of third segment.

Maxillipedal basis (fig. 7k) with two receptacula. Segment 2 of palp widest; widths of palp segments $2-5$ relative to first segment 1.2, 0.9, 0.9, 0.5, respectively. Epipod 2.0 times longer than wide, with single seta on ventral side.

Pleopod II 1.2 times longer than wide with setae on lateral edges.

Remarks. - This new species differs from Munella danteci in a number of points. Judging from Bonnier's (1896) seemingly accurate illustrations, the pereon of the male $M$. danteci is broader than long, in contrast to the more slender pereon of the male $M$. gayda. The setation of the males differs significantly between the two species, $M$. danteci being far more setose. On the other hand, the female of $M$. gayda shows similarities to $M$. danteci in the number of setae on the pereon. Unfortunately, Bonnier had only a single male for description. $M$. danteci is shown with 11 articles on the first antenna. However, it is probable that Bonnier missed the tiny 12 th article that is present on $M$. gayda. The mandibular palp is clearly longer than the body of the mandible on $M$. danteci. The distal margin of pleopod I of the males of $M$. gayda is convex while it is concave on $M$. danteci. Further comparisons between these two species are presently impossible since the holotype for $M$. danteci does not exist (R. Ginet, personal communication).

Derivation of name. - Gayda refers to the Gay Head-Bermuda Transect.

\section{RÉSUMÉ}

Cinq nouvelles espèces aberrantes d'Isopodes parasellotes ont été recueillies au cours des campagnes $\mathrm{n}^{\circ} 24,31$ et 60 de $\mathrm{I}_{3}$, Atlantis II" dans l'Atlantique nord et équatorial. Deux nouveaux gentes, Thylakogaster (avec trois espèces) et Abyssaranea (une espèce) ont été établis pour recevoir 
des espèces d'une morphologie exceptionellement inhabituelle. Abyssaranea montre beaucoup de similarités avec Munella (une espèce décrite dans cet article). Alors que ces genres sont nettement apparentés à ceux qui sont actuellement inclus dans les Munnidae et les Dendrotionidae, leur position familiale particulière est incertaine.

\section{BIBLIOGRAPHY}

Bonnier, J., 1896. Edriophthalmes. Ann. Univ. Lyon, 1895: 527-689.

Hessler, R., 1970. The Desmosomatidae (Isopoda, Asellota) of the Gay Head-Bermuda Transect. Bull. Scripps Inst. Oceanography, 15: 1-185.

Hessler, R. \& H. Sanders, 1967. Faunal diversity in the deep-sea. Deep-Sea Research, 14: 65-78.

Lo Bianco, S., 1903. Le pesche abissali eseguite da F. A. Krupp col yacht Puritan nelle adiacenze di Capri ed in altre localita del Mediterraneo. Mitt. zool. Stat. Neapel, 16: 109-279.

Menzies, R., 1962. The zoogeography, ecology, and systematics of the Chilean marine isopods. Handl. Fysiogr. Sellsk. Lund, (n. ser.) 72 (11): 1-162.

SANDERS, H., R. Hessler \& G. Hampson, 1965. An introduction to the study of deep-sea benthic faunal assemblages along the Gay Head-Bermuda transect. Deep-Sea Research, 12: 845-867.

VANhöffen, E., 1914. Die Isopoden der Deutschen Südpolar-Expedition 1901-1903. Deutsche Südpolar-Exped., 15 (4): 449-598.

WOLFF, T., 1962. The systematics and biology of bathyal and abyssal Isopoda Asellota. Galathea Rep., 6: 1-320. 